\title{
Strategies to Attract Private Transport to Public Transport
}

\author{
Yulinar Rizky Damayanti ${ }^{1 凶}$, Lesta Karolina Br Sebayang ${ }^{2}$ \\ Jurusan Ekonomi Pembangunan, Fakultas Ekonomi, Universitas Negeri Semarang \\ Permalink/DOI: https://doi.org/10.15294/efficient.v2i3.35912
}

Received: Juny 2019; Accepted: September 2019; Published: December 2019

\begin{abstract}
The purpose of this research is to develop appropriate policy strategies to attract users to switch modes from private transport to public transport. This research is quantitative research. This research uses the Analysis Hierarchy Process (AHP). The number of interviewees in this study as many as 8 keyperson. Research results indicate that transportation is the most criteria priority has a value weight of 0.612 , then the user's criteria of 0.251 became the second prioritized criteria, and the last is the policy criteria the Government of 0.137. Based on the results of the research of the advice given by researchers, namely; the rejuvenation of old age transportation, provide coaching to driver-driver BRT, adding to the shelter-shelter at points of housing and shopping, as well as add new routes in order to reach out to suburban areas.
\end{abstract}

Keywords: Private Transportation, Public Transportation Analysis Hierarchy Process

\begin{abstract}
Abstrak
Tujuan dari penelitian ini adalah untuk mengembangkan strategi kebijakan yang tepat untuk menarik pengguna untuk beralih moda dari angkutan pribadi ke angkutan umum. Penelitian ini adalah penelitian kuantitatif. Penelitian ini menggunakan Analisis Hierarki Proses (AHP). Jumlah yang diwawancarai dalam penelitian ini sebanyak 8 keyperson. Hasil penelitian menunjukkan bahwa transportasi adalah prioritas kriteria terbanyak yang memiliki bobot nilai o,612, maka kriteria pengguna 0,251 menjadi kriteria prioritas kedua, dan yang terakhir adalah kriteria kebijakan Pemerintah o,137. Berdasarkan hasil penelitian atas saran yang diberikan oleh peneliti, yaitu; peremajaan transportasi usia tua, memberikan pembinaan kepada pengemudi-pengemudi BRT, menambah shelter-shelter di titik-titik perumahan dan perbelanjaan, serta menambah rute baru guna menjangkau wilayah pinggiran kota
\end{abstract}

Kata Kunci: Transportasi pribadi, analisa angkutan umum proses hirarki

How to Cite: Damayanti, Y., \& Sebayang, L. (2019). Strategies to Attract Private Transport to Public Transport. Efficient: Indonesian Journal of Development Economics, 2(3), $100-123$. https://doi.org/10.15294/efficient.v2i3.35912

(C) 2019 Semarang State University. All rights reserved

\footnotetext{
Alamat Korespondensi :

Alamat: Gedung L2 Lantai 2 FE Unnes

Kampus Sekaran, Gunungpati, Semarang, 50229

E-mail : yulinarrizkydamayanti@gmail.com
} ISSN 2655-6197 


\section{INTRODUCTION}

Transport is an activity the transfer or transport of goods and people from one place to another place. The transportation system is a tool to ensure the delivery of goods and services as one of the indicators for the economic prosperity and economic growth, as well as contributing to the quality of life (Sebayang, 2011).

Central Java have the congestion problem resulting from advances in the field of land transport. The Government should pay more attention to the existence of the progress in the field of land transport. Advances in ground transport very bring benefits but also bring problems if not set in such a way. Transportation problems can be addressed by policies that pro public transport (Online, 2016). Semarang City's transportation policy, namely, developing a ring road, improving transportation mode services that support the growth and development of urban activity service centers, developing public transportation systems, developing public transport terminals and increasing inter-modal system integration.

The city of Semarang in Central Java's capital city which has high mobility currents. According to the Central Bureau of statistics (BPS) Semarang City area of Semarang city every year there is no expansion of the land from the year 2013 to 2017373.70 Semarang city land area $\mathrm{km} 2$ and a total population of Semarang city each year have always risen to in the year 2017 amounted to $1,757,686$ inhabitants. In the absence of the addition of land and increasing population will be accompanied with high population density. The level of density of a comparison between the number of people living in a particular area with the area they inhabit.

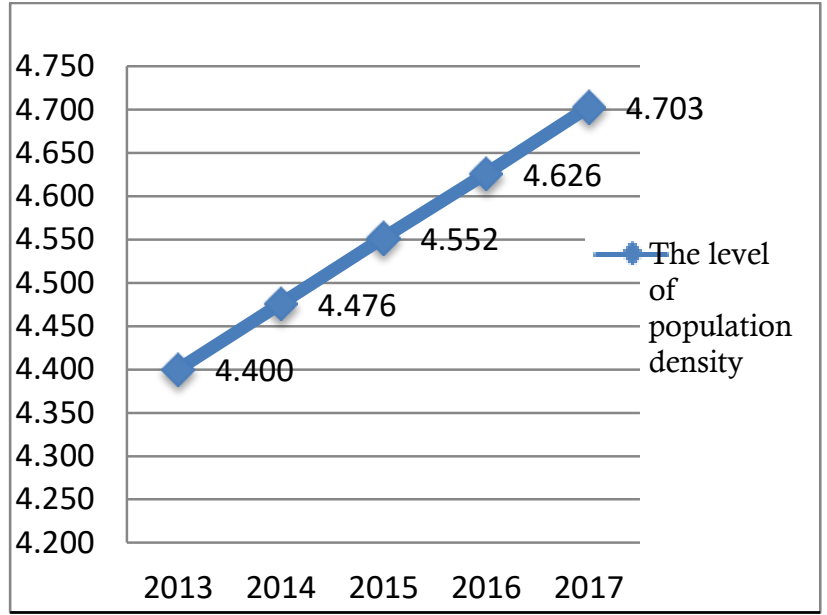

Figure 1 rates of population density of Semarang Year 2013-2017

Source: Central Bureau of statistics in Central Java, processed

Based on Figure 1 above shows that in the city of Semarang annually the level of population density increases, the population density in the year 2013 Semarang city of 4,400 people/km2 up to 2017 in Semarang city population density continues to increased to 4,703 people $/ \mathrm{km} 2$. The population density in the city of Semarang to happen because there are several factors which affected it one of these economic factors. With increased population density seiringnya would have been accompanied by a high mobility also requires transportation to support mobility.

Broadly speaking there are two large groups of transportation modes, i.e., private transport and public transport. Private transport is transport that gives freedom of operations for wear and traveled everywhere, anywhere and anytime, and travel faster is not subject to time. While the public transport passenger public transport is made by the system or pay rent. The main purpose of the existence of private transport was organized 
good service and worth to the community. In the efficiency in the use of public transport more efficient in using the roads rather than private transport (Djakfar et al., 2010).

Table 1. Data of the number of motor vehicles in the city of Semarang 2013-2017

\begin{tabular}{lllll}
\hline No & Years & Transport Wheels 2 & Transport Wheels 4 & Total \\
\hline 1 & 2013 & 854.043 & 141.735 & 995.778 \\
2 & 2014 & 991.602 & 162.538 & 1.154 .140 \\
3 & 2015 & 1.152 .521 & 182.774 & 1.335 .295 \\
4 & 2016 & 1.307 .600 & 203.152 & 1.510 .752 \\
5 & 2017 & 1.532 .679 & 448.529 & 1.981 .208 \\
\hline
\end{tabular}

Source: property management Income Area of Central Java province, 2017

Based on table 1 that the number of transport wheels 2 and 4 wheeled transportation in Semarang city always increase every year. In the year 2013 total bermotornya of vehicle 995,778 . Then the year 2014 into 1,154,140 of 995,778 motor vehicles. In the year 2015 would also increase by 181,155 motor vehicles and in the year 2016 total motor vehicles increased again became 1,510,752 later in the year 2017 private transport increased back amounted to $1,981,208$. According to the Central Bureau of statistics (2016) long road in the whole area of Semarang reached 2,785.28 $\mathrm{km}$ up to this point there is no addition of a street in the city of Semarang and a continued rise in the number of motor transport in Semarang city resulted in a density the road.

The density of traffic on a road affected by several factors, including the condition of the roads and the environment, with regard to time, cost, and distance. Bad road conditions as many wavy and perforated causing slow so speeds transportation travel time increased, the motor transport types also affect the selection of paths or roads that will pass the transport. This can lead to the buildup of traffic on a specific road.
Semarang City Government in 2010 has been providing this type of public transportation in the form of Bus Rapid Transit BRT known as Trans Semarang. Expected Bus Rapid Transit (BRT) is one of the solutions used in other major cities in Indonesia for people to use public transportation nyamaan and resolve bottlenecks. BRT is one type of public transport which provides faster and more efficient than other similar means of transport. BRT route and well-integrated. The same good rate all circles because of distance or near (Semarang, 2017).

Based on the transport Masterplan Semarang city bus-based public transport, such as the BRT public transport is the right applied in the city of Semarang in order to reduce the congestion would be private vehicles are on the rise.

Based on Figure 2 since beroprasinya BRT Trans Semarang patronage is always increasing. However in the year 2017 corridor II experienced a decline in the number of passengers who originated in the year 2016. BRT Trans Semarang still have low quality on its application. The lack of information boards BRT, less teduhnya stops and the time that it 
takes a community to make Semarang BRT can not switch to using public transport and Government policies holding the public transport to alleviate traffic congestion has not yet resolved. Based on the description of the background, then the aim in this study is to devise appropriate policy strategies to attract users to switch mode of private transport to public transport in the city of Semarang.

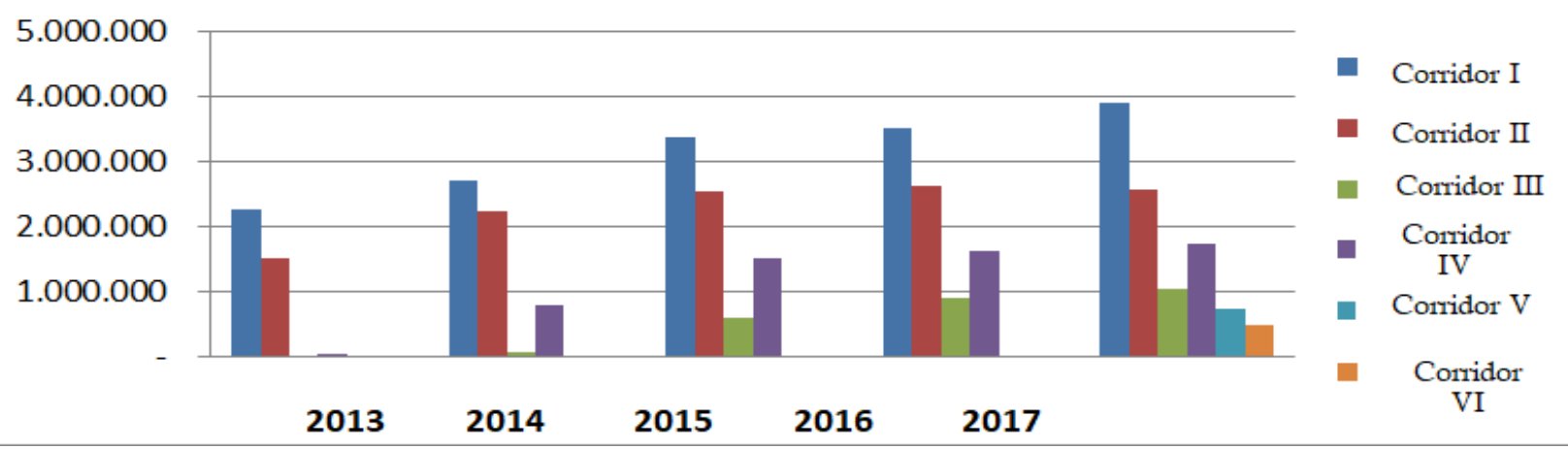

Figure 2. number of BRT Passengers in Semarang City Year 2013-2017

Source: Department Of Transportation City Of Semarang

\section{METHOD}

The type of research that used this is quantitative research. Types of data used in this research is the primary data. Primary data in this study obtained by the technique of observation, questionnaires and interview against 8 keyperson associated directly in the field of transport in the city of Semarang. This research using the method of Analysis Hierarchy Process (AHP). Analysis Hierarchy Process (AHP) is used to find out which aspects of the program should be given priority and precedence in drawing up the policy of transport in the city of Semarang. Three principles that must be understood to resolve a problem by the method of AHP: decomposition, comparative judgement, and logical consistency (Walangare et al., 2012). The variables used in this study is the variable Analysis Hierarchy Process (AHP), namely in the form of an alternative policy or strategy to make the user can switch from private transport to public transport. The variables in the study as follows: Aspects Of Government Policy, Aspects Of Transport, Aspects Of The User. The concept of Analysis Hierarchy Process on this research can be seen in the following image:



Figure 3. Concept research of AHP 
Description:

$\mathrm{A}_{1}=$ Improvements of public transport

$\mathrm{A}_{2}=$ restrictions on private transportation

$\mathrm{A}_{3}=$ addition of road network

$\mathrm{B}_{1}=\mathrm{a}$ decrease in the percentage of the transport of old age

$\mathrm{B}_{2}=\mathrm{a}$ progressive transportation Taxes based on results of the exhaust emission tests

B3 = the embodiment of the slow lane and bike path

$\mathrm{C}_{1}=$ increased safety and comfort on public transport

$\mathrm{C}_{2}=$ infrastructure and facilities on public transport in fix

$\mathrm{C}_{3}=$ faster travel time

Set priority elements in a question of the decision is to make a comparison in pairs, i.e., each element is compared in pairs to a specified criteria.

Table 2. The Scale Of The Pair's Appeal

\begin{tabular}{ll}
\hline Value & Description \\
\hline Value 1 & $\begin{array}{l}\text { Both factors are equally important } \\
\text { One factor is a little more important } \\
\text { than the other factors }\end{array}$ \\
Value 5 & $\begin{array}{l}\text { One of the essential factors or other } \\
\text { factors are more important than }\end{array}$ \\
Value 7 & $\begin{array}{l}\text { One factor is clearly more } \\
\text { important than the other factors }\end{array}$ \\
Value 9 & $\begin{array}{l}\text { One factor is absolutely more } \\
\text { important than other factors } \\
\text { Value }\end{array}$ \\
2,4,6,8 balues between two values, & between Scamp considerations
\end{tabular}

Source : (Prajanti, 2013)

Skala It defines and explains the value of

1 to 9 are specified as a consideration in comparing elements of similar couples in every level of the hierarchy to a criteria that are a notch above. Pairing the appeal scale used in the preparation of AHP to determine the order of priority of alternative criteria in order to achieve a goal that is crafting a policy that users switch from private transport to public transport BRT (Prajanti, 2013).

\section{RESULTS AND DISCUSSION}

The policy strategy to attract users of private transportation to public transportation in Semarang City was prepared using the Analysis Hierarchy Process (AHP) method. Based on the opinions of each keyperson, the transportation criteria are the most important or prioritized criteria in an effort to attract users to switch from private transportation to public transportation in the city of Semarang. After the transportation criteria then have the criteria of users as the second priority, then there are criteria for government policy as the third and final criteria. The following is a picture of 4 policy strategy criteria to attract users to switch private transportation to public transportation in the city of Semarang using expert choice 11 software.

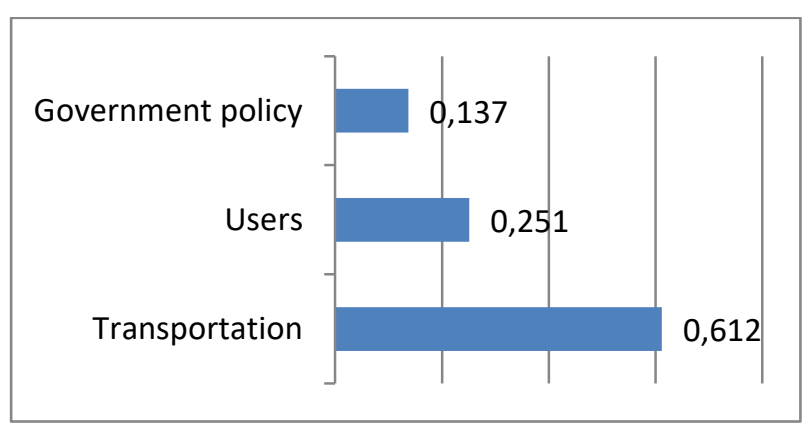

Figure 4. AHP Output Criteria Policy Strategies to Attract Users to Switch Private Transportation to Public Transportation Source: 2018 primary data, processed 
Based on Figure 4 the criteria that found the highest weighting value was transportation criteria of 0.612 so that the government had to pay more attention to transportation criteria to be better addressed to attract users to switch to transportation modes, then the user criteria found second place at 0.251 , and government policy criteria ranked third o.137. After the transportation criteria have been addressed, then the criteria for users who become the second priority are considered and continued with the criteria of government policy. If the transportation criteria are already running, of course, it will make private transportation users use public transportation and are lazy to use their personal transportation on the grounds of tax problems. The second priority is the user criteria which includes user comfort and security. If public transportation is safe and comfortable, private transportation users will switch to using public transportation because if public transportation is not safe and comfortable, users will be lazy to use public transportation, it is still safe to use private transportation, thus according to consumer behavior theory which states that from the start not satisfied then someone will be more careful in using it again. The criteria for government policy in the third priority position which includes the policy of reforming public transportation on government policy priorities are also important to see the government continue to push for improvements in public transportation but the improvement of public transportation itself is not optimal because public transportation in the form of BRT is still not flexible in serving the periphery and not yet separated BRT special lane. The next step that must be done is to describe each policy criterion based on the most prioritized sequence to the less prioritized into the alternatives of each criterion

The first priority criteria are transportation criteria. The first is the decline in the percentage of transportation in old age is the policy that is in the master plan of the City of Semarang. The aim of this policy is that public transportation that is already old is no longer used so that it is hoped that people can use public transportation that is safe and certainly comfortable. Then there is a progressive transportation tax based on the results of the exhaust emissions test, then the third is the realization of the slow path. In addition to supporting users to use private transportation these alternatives can also improve the quality of the environment in the city of Semarang.

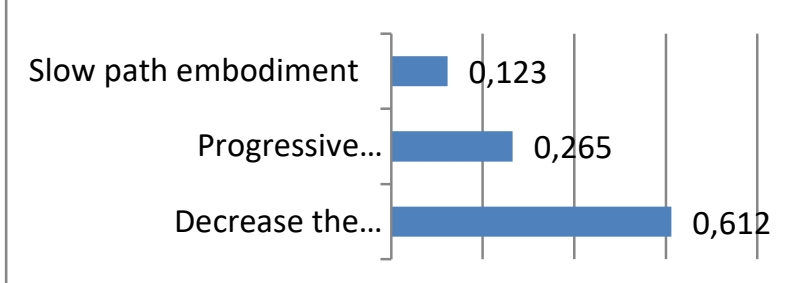

Figure 5. AHP Output Transportation Criteria Source: 2018 primary data, processed

In Figure 5 shows an alternative to the criteria of transportation which found the greatest weighting value, namely an alternative reduction in the percentage of transportation age of 0.612 , then the second alternative is a progressive transportation tax based on the exhaust gas emission test results of 0.265 , and the third alternative namely the embodiment of the slow lane 0.123 .

The second priority criteria is the User Criteria. It can be identified that more attention is needed to improve security and comfort in public transportation in attracting 
users to switch from private transportation to public transportation in the city of Semarang. The community or users who want to use public transportation are safe and comfortable, besides that the facilities and infrastructure on public transportation must be improved because if the facilities and infrastructure are feasible, security and comfort can follow. Faster travel time is also necessary, but the public prioritizes security and comfort in switching modes of transportation.

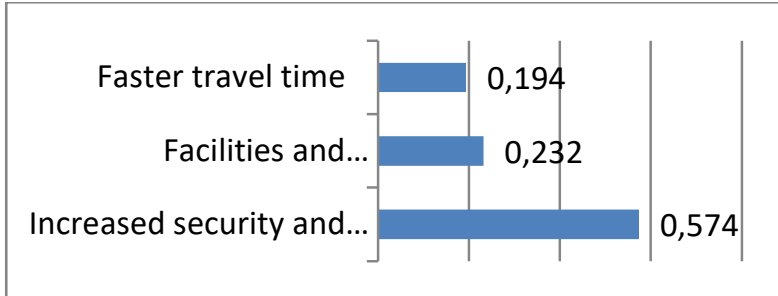

Figure 6. AHP Output Transportation Criteria Source: 2018 primary data, processed

Based on AHP calculations in Figure 4.4 shows that the most prioritized alternative in attracting users to switch from private transportation to public transportation in the city of Semarang through user criteria is an increase in security and comfort in public transportation has a weight value of 0.574 . Then the second alternative priority is that the facilities and infrastructure in public transportation are fixed to have a weight value of 0.232 and the third alternative is faster travel time with a weighting value of 0.194 .

The third priority criterion is Government Policy. This means that the improvement of public transportation is carried out periodically by public transportation. The fleet only has a usage period of around 5-10 years. If it is not feasible, the fleet will be terminated because it also fears the safety and comfort of public transportation users. The government always has an effort to attract people to switch to using public transportation, one of which is the limitation of private transportation, but in Semarang there is no such thing so that people are still free to buy private transportation, so public transportation is not at all glimpsed by the community.

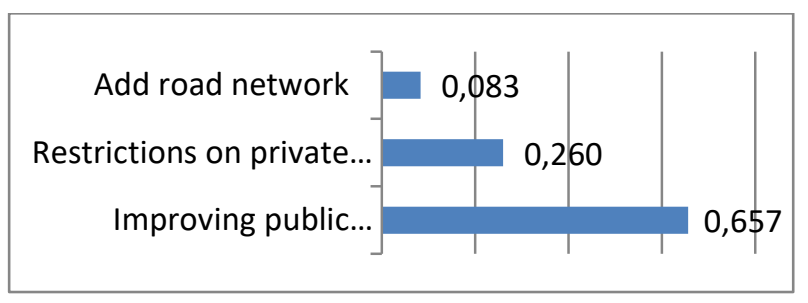

Figure 7. AHP Output Criteria for Government Policy

Source: 2018 primary data, processed

Based on the AHP calculation in Figure 7 shows that the most prioritized alternative is the improvement of public transportation which has a weight value of 0.657 . Then the second alternative priority is the limitation of private transportation which has a weight value of 0.260 and the third alternative is the addition of a road network that has a weight value of 0.083 .

Based on the results of the overall AHP analysis, the alternative reduction in the percentage of old age transportation is the most prioritized compared to other alternatives in attracting users to switch from private transportation to public transportation in the city of Semarang. The order of policy strategies to attract users to switch private transportation to public transportation in the city of Semarang as a whole based on AHP calculations can be seen in figure 8 . 


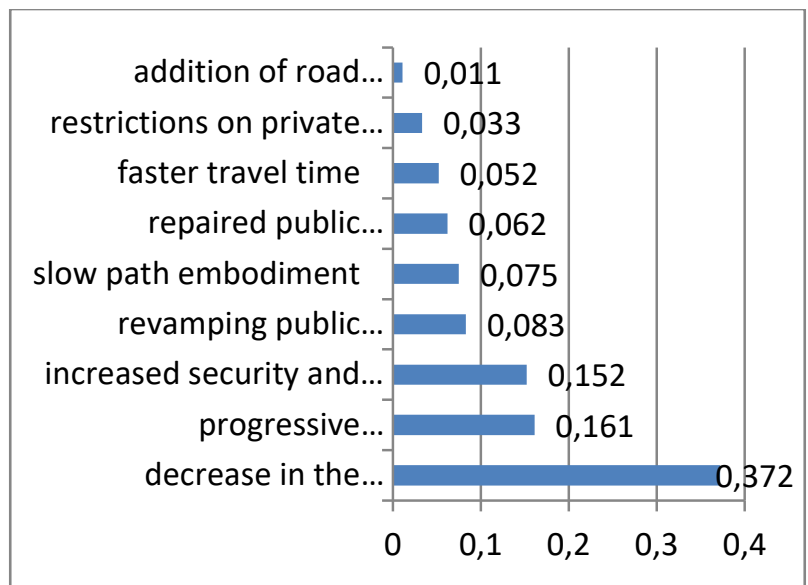

Figure 8. AHP Output Sequence Policy Strategy to Attract Users Switching Private Transportation to Public Transportation in Semarang City

Source: 2018 primary data, processed

Based on Figure 8, the preferred or prioritized alternative is the reduction in the percentage of old age existing in the transportation criteria, as explained earlier if the government should prioritize the reduction in the percentage of old age transportation so that private transportation users will switch to using public transportation in the form of BRT. After the first alternative, a second alternative has been made, namely a progressive transportation tax based on the results of the exhaust emission test which is no less important than the first alternative is also carried out to attract private transportation users to switch modes of transportation then followed by further alternatives.

A decrease in the percentage of the transport of old age is still pretty tough in the city of Semarang while the transport of old age is very disturbing in the streets because the gas buangnya that can interfere with other road users and can harm the users of public transport. A variety of reasons that become obstacles to attracting private transport users switch to using public transport is to be found the solution, that achieved the purpose well for the sake of personal transport users to switch to public transport.

the second priority is a progressive transportation taxes based on results of the exhaust emission tests. The second alternative is also important to attract users to use public transport because if taxes are imposed based on the results of the exhaust emission tests determine the imposition of tax if it exceeds a threshold required then it will be affect the magnitude of the tax, the public will feel burdened transport that uses old age with the assumption the older transport then tax will be more expensive. However, in this policy is still not optimal in addressing transportation percentage of old age. So still need evaluation and repair of a progressive transportation taxes based on results of the exhaust emission tests. Moreover, it can improve the environment in the city of Semarang because exhaust gas transport is also very disturbing human health.

An alternative third priority is the improvement in transportation safety and comfort of the public, these alternatives from the user's criteria. On BRT Semarang city masterplan in terms of design and specification of bus must meet some specified criteria associated with standard service, level of comfort, safety and security to be provided to passengers. On conditions in the field of security and comfort on public transportation is still considered less for users of public transport and private transport use felt still comfortable and secure. Still the presence of the driver of the BRT that inconsiderate, if a bus full of passengers between men and women look like mixed while already running it already separated so that passengers are 
women uneasy if have to jostle with men passengers. BRT should it secure than using private transport, BRT is also designed in order for the community to use it but it is in a State in the way of common BRT inconsiderate. Whereas BRT track still along with other transportation in Semarang city unlike the city of Jakarta which the BRT line already divided with other transportation.

Based on AHP calculations, some alternative strategies that have characterized, duties, and functions that are equally important to each problem as already described three alternatives the most prioritized. With the right implementation based on priorities and conditions in the field, some constraints and problems that were previously expected to occur are also able to be solved by this strategy alternatives.

\section{CONCLUSION}

Based on the results of the Analysis Hierarchy Process (AHP) data, it can be seen that the transportation criteria are the most prioritized criteria, then the second priority of the user criteria, and the last is the criteria for government policy. The government must pay more attention to the alternatives of the transportation criteria so that they are better addressed to attract users to switch modes of transportation after that, followed by the second and third priority criteria. Then the priority programs that are prioritized are as follows; declining percentage of old age transportation, progressive transportation tax based on the results of exhaust emissions testing, increased safety and comfort in public transportation, improvement of public transportation, realization of slow lanes, improved facilities and infrastructure for public transportation, faster travel times, restrictions on private transportation, and the addition of road networks.

\section{REFERENCES}

Djakfar, L. et al. (2010). Characteristics Study and Selection Model of Student Transport Moda Towards Campus (Motorcycle or Public Transportation) in Malang City. Civil Engineering Journal, 37-51.

Morlok, E. K. (1978). Introduction to Engineering and Transportation Planning. Jakarta: Erlangga Publisher.

Online, P. J. (2016). Serious Work Needs the Provincial Government to Overcome the Problems of Land Transportation in Central Java. Semarang: PKS Central Java Online.

Prajanti, S. D. (2013). Methods of Production Efficiency Analysis and Decision Making in the Agricultural Economy. Semarang: UNNES PRESS.

Sebayang, L. K. (2011). Analysis of the Linkage of Infrastructure Availability and Economic Growth in Indonesia: Approach to Granger Causality Analysis. TRACK, Volume 4, 14-22.

Semarang, T. (2017). Profile of Trans Semarang. Picked February 16, 2018, from http://transsemarang.semarangkota.go.id/portal/ page/ppid/344/trans-semarang-profil-transsemarang

Statistics, B. P. (2016, April 8). Semarang City Statistic Center. Picked February 16, 2018, from https://semarangkota.bps.go.id/

Law of the Republic of Indonesia Number 22 of 2009 concerning Traffic and Road Transportation

Walangare, D. et al. (2012). Football Match Prediction System with Analytical Hierarchy Process (AHP) Method. Informatics, Volume 8, 181-188. 